\title{
Selection of prosperous varieties of rosehips (rosa L.) And their seed productivity in Tashkent oasis, Uzbekistan
}

\author{
$F$ Ubaydullayev $^{1, *}$ and $S h$ Gaffarov $^{1}$ \\ ${ }^{1}$ Tashkent State Agrarian University, Universitetskaya str., 2, 100140, Tashkent, Uzbekistan
}

\begin{abstract}
Rosehips fruit contains organic and inorganic substances, the most valuable compounds among organic substances are vitamins, which are accumulated in the flesh of the fruit, and they have important physiological effects for living organisms. The obtained experimental data were statistically processed by the method of analysis of variance. Many selected varieties of rosehips were unique not only in the size of the fruit, but also in the high seed yield: an average of $28.7 \pm 0.65$ pieces in the fruits of "Sijjak-5", $29.1 \pm 0.66$ pieces in the fruits of "Sijjak-6", $33.9 \pm$ 0.93 fruits in "Sijjak-7", $28.7 \pm 0.66$ fruits in "Sijjak-15" and $29.3 \pm 0.64$ fruits in "Burchmullo-18". Rosehips seeds contain "rosehips oil", which contains $10 \mathrm{mg} \%$ carotene, $200 \mathrm{mg} \%$ vitamin $\mathrm{E}$, linoleic (56.71\%) and oleic (29.32\%) acids. "Sijjak-3", "Sijjak-6", "Sijjak-12" and "Chimgan19 " were selected as promising varieties, taking into account the valuable economic and biological characteristics of the fruit, such as size, productivity and fertility. Varieties "Parkent-21" and "Parkent-24", according to the size of fruits and the amount of fruit flesh, whereas Parkent-26, "Kumushkon-29", "Parkent-23", "Chimgan-31", "Koronkul"32 were classified as promising varieties based on the highest yield.
\end{abstract}

\section{Introduction}

Among vitamin-rich plants, rosehips ranks first in terms of vitamin activity, its fruits contain provitamins, such as $\mathrm{V} 1, \mathrm{R}, \mathrm{K}, \mathrm{E}$ and $\mathrm{A}$, in addition to the main vitamin $\mathrm{C}$ (ascorbic acid) $[3-5,14]$. The natural mountain forests of the republic are rich in medicinal shrubs, among which the fruit of rosehips, the fruit of which is called "natural vitamin concentrate", has a special place. Rosehips fruits contain vitamin C (1-8\%), according to which there is no equivalent plant species in the world flora. Of the 17 naturally occurring species of rosehips (Rosa L.) in Uzbekistan, 14 species are found in the Western Tien Shan. Vitamin preparations such as arfazetin, bronchium, carotene, rozanol, kholosas, rosehips syrup, and rosehips balm are produced based on Rosehips fruits [1, 2]. They are widely used in the treatment of hemophilia, atherosclerosis and gastrointestinal diseases. Rosehips fruits contain large amounts of trace elements potassium, manganese, calcium and magnesium, the seeds of which are rich in vitamin E "rosehips oil" [1,2]. Rosehips fruit

\footnotetext{
${ }^{*}$ Corresponding author: f.a8dullayev@yandex.com
} 
contains organic and inorganic substances, the most valuable compounds among organic substances are vitamins, which are accumulated in the flesh of the fruit, and they have important physiological effects for living organisms. These compounds, which are required in small amounts relative to protein, fat and carbohydrates, enter the enzyme molecule and participate in metabolism in tissues [4-6].

Cultivation and selection of rosehips began in the 1940s at the Vorontsov Experimental Station of the All-Russian Research Institute of Vitamins and later continued at the AllRussian Institute of Medicinal and Fragrant Plants. Large rosehips plantations established in Russia in the 60s and 70s of the last century were mainly based on seedlings of rosehips species rich in vitamins such as Rosa cinmamomea, Rosa rugosa, Rosa acicularis and Rosa laxa $[4,8,9]$. The rosehips selection module was firstly developed and tested in the scientific research conducted at All-Union Research Institute of Agroforestry. Accordingly, there are 3 ways to cultivate rosehips on the plantation $[3,4]$. The first is to establish plantations based on seedlings of high-vitamin rosehips varieties. The second is the selection of large-fruited, varieties rich in vitamins and the selection of varieties with valuable economic and biological characteristics. The third is to apply the interspecific hybridization method towards more productive hybrids in the term of vitamin $\mathrm{C}$ content and yield level.

\section{Materials and methods}

Selection of promising varieties of rosehips was done in the mountainous villages, such as Sijjak, Nanay, Yakkatut, Burchmulla of Bostanlyk district and Kumushkon, Hisarak, Zarkent (Western Tien-Shan) of Parkent district. Rosehips plantations and partial plantations of rosehips were planted in Burchmulla, Tashkent and in Parkent forest. Evaluation of the selected positive varieties on the basis of valuable economic and biological characteristics was carried out on the basis of a 5-point system in accordance with the requirements of the manual "Program and methods of sorting of fruit, berry and orexoplodovyh cultures" (1999) [4,9]. The size of the fruits of rosehips was determined by the weight of 100 freshly picked fruits and was evaluated as follows:

1 point - very small fruits - weight of 100 fruits up to 200 grams;

2 points - small fruits - $210-250 \mathrm{~g}$;

3 points - average fruit size $-260-300 \mathrm{~g}$;

4 points - large fruits - 260-300g;

5 points - the fruits are very large - 310 grams and above

Rosehips seeds are an important raw material for planting material as well as for the pharmaceutical industry - they provide valuable "rosehips oil". The selected varieties were evaluated as follows:

1 point - very few seeds - the fruit contains up to 10 seeds;

2 points - low-seeded - 11-15-seeded;

3 points - average seed - 16-20 seeds;

4 points - multi-seeded - 21-25 seeded;

5 points - rich in seed - 26 and more;

Based on the results of the complex assessment of the valuable economic and biological characteristics of the varieties of rosehips, among them the varieties with a value of more than 4 points on the valuable economic and biological characteristics were distinguished as promising varieties $[6,7,9]$. Field experiments, laboratory analysis and statistical methods were used in the research. The obtained experimental data were statistically processed by the method of analysis of variance, and the smallest significant differences were identified. Analysis of experimental data was carried out based on B. A. Dospekhov's methods [2, 3]. 


\section{Results and discussion}

The selection of positive varieties of rosehips was conducted in August-September. The positive varieties of nectar selected during the study were evaluated mainly based on fruit indicators and biochemical composition. Table 1 showed that the largest fruits were in "Sijjak-3" variety (fruit length was $2.9 \pm 0.02 \mathrm{~cm}$, fruit weight was $4.0 \pm 0.05 \mathrm{~g}$, fruit yield was 75\%), "Sijjak-6" (3.5 $\pm 0,04 \mathrm{~cm} ., 6.4 \pm 0.19 \mathrm{~g}$ and $78.1 \%)$, "Sijjak-7" (2.7 \pm 0.03 $\mathrm{cm} ., 4.1 \pm 0.06 \mathrm{~g}$ and $73.1 \%)$, and in "Chimgan-19" $(3.4 \pm 0.06 \mathrm{~cm}, 5.6 \pm 0.14 \mathrm{~g}$ and $75 \%)$.

Many selected varieties of rosehips were unique not only in the size of the fruit, but also in the high seed yield: an average of $28.7 \pm 0.65$ pieces in the fruits of "Sijjak-5", $29.1 \pm$ 0.66 pieces in the fruits of "Sijjak-6", $33.9 \pm 0.93$ fruits in "Sijjak-7", $28.7 \pm 0.66$ fruits in "Sijjak-15" and $29.3 \pm 0.64$ fruits in "Burchmullo-18". The fertility of the rosehips fruit was considered a valuable selection trait, and it was taken into account in distinguishing promising varieties. Rosehips seeds contain "rosehips oil", which contains $10 \mathrm{mg} \%$ carotene, $200 \mathrm{mg} \%$ vitamin E, linoleic $(56.71 \%)$ and oleic $(29.32 \%)$ acids. This oil is similar to retail oil in terms of pharmacological activity [3]. Due to the lack of thorns in the generative branches, the Sijjak-6 form was an interesting object for selection purposes. It was noted that the main part of the selected rosehips varieties in the mountain villages of Bostanlik district belong to the species of doubtful rosehips (Rosa ambigua N. Russanov). Seed yield from $1 \mathrm{~kg}$ of freshly picked fruits of rosehips was on average $22-35 \%$. This figure was the lowest in Fedchenko's favor - 17.4\%. The weight of 1000 seeds of rosehips was an individual indicator, large grains were formed in large fruits, and small tetrahedral seeds were formed in small fruits. It was noted that this figure was around 37-68 grams in all selected positive varieties. A brief morphological description of the selected positive shrubs of rosehips in the Western Tien Shan was given below.

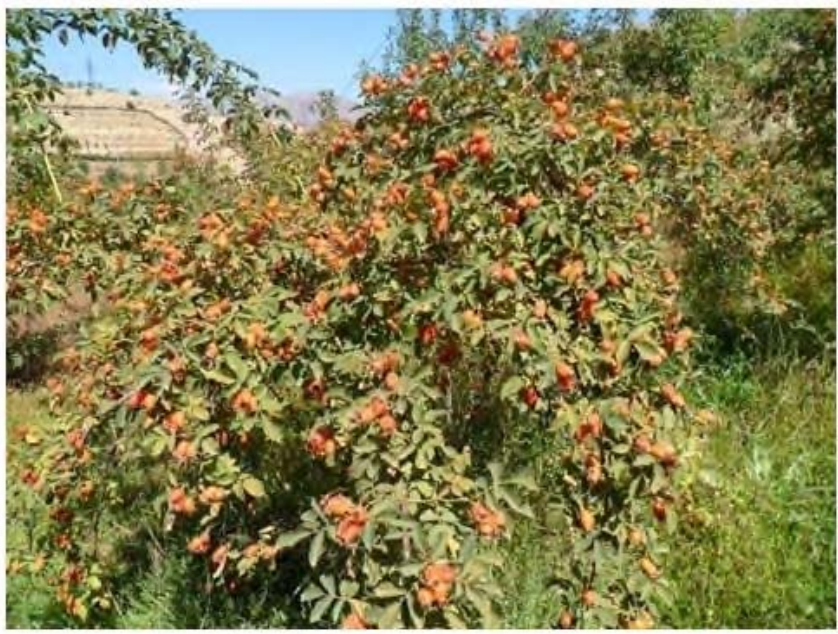

Fig. 1. Sijjak-5 positive form of rosehips.

"Koronkul-1" variety. The height of the bush was $2 \mathrm{~m}$ and the average yield was $5 \mathrm{~kg}$. The fruit was cup-shaped, $2.7 \pm 0.03 \mathrm{~cm}$ long and weighs $4.6 \pm 0.07 \mathrm{~g}$. Fruit flesh was made up $73.9 \%$ of fruit weight. The fruits were juicy, with an average of $31.4 \pm 0.52$ seeds per fruit, each weighing 37 grams.

"Sijjak-2" variety. The height of the bush was $2.5 \mathrm{~m}$, and the average yield was $4 \mathrm{~kg}$. The fruit is cup-shaped, the fruit was $3.0 \pm 0.03 \mathrm{~cm}$ long and weighs $3.7 \pm 0.04 \mathrm{~g}$. Fruit 
flesh was made up $70.0 \%$ of the total fruit weight. The fruit contains $24.3 \pm 0.99$ seeds, the weight of 1000 seeds was 43.5 grams.

"Sijjak-5" variety. The height of the bush was $2.7 \mathrm{~m}$, and the average yield was 3.5 $\mathrm{kg}$. The fruit as elongated, $2.8 \pm 0.02 \mathrm{~cm}$ long and weighs $4.3 \pm 0.08 \mathrm{~g}$. The amount of fruit flesh was $67.4 \%$. The fruits contained $28.7 \pm 0.65$ seeds, and the weight of 1000 seeds was 48.2 grams (Figure 1).

"Sijjak-6" variety. The shrub height was 2.3 , and the average yield was $4 \mathrm{~kg}$. The fruit was elongated, $3.5 \pm 0.04 \mathrm{~cm}$ long, and weighs $6.4 \pm 0.19 \mathrm{~g}$. The flesh content of the fruit was $78.1 \%$.The fruits contained $29.1 \pm 0.66$ seeds, and the weight of 1000 seeds was 52.7 grams. It was a valuable variety for breeding purposes with no thorns on the fruiting branches (Fig. 2).

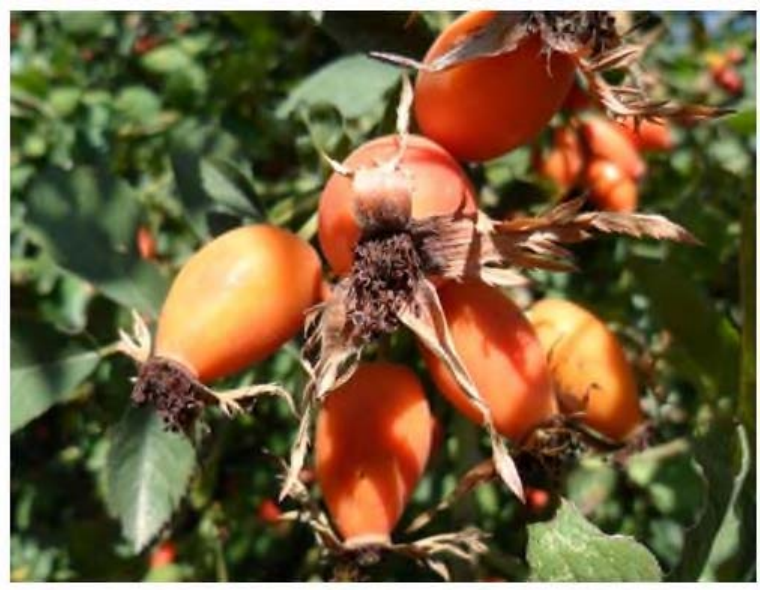

Fig. 2. "Sijjak-6" positive form of rosehips.

"Sijjak-11" variety. The height of the bush was $4 \mathrm{~m}$ and the average yield was $5 \mathrm{~kg}$. The fruits were large, cup-shaped, $2.9 \pm 0.05 \mathrm{~cm}$ long and weigh $4.1 \pm 0.10 \mathrm{~g}$. The yield of fruit flesh was $73.1 \%$. The fruit contained $20.0 \pm 0.62$ seeds. The weight of 1000 seeds was 46.9 grams.

"Nanay-13" variety. The height of the bush was $3 \mathrm{~m}$, and the average yield of the bush was $6 \mathrm{~kg}$. Fruit was cup-shaped, length $2.9 \pm 0.03 \mathrm{~cm}$, weight $3.3 \pm 0.08$ gram. Fruit flesh yield was $75.7 \%$. The fruits contained $16.5 \pm 0.46$ seeds and the weight of 1000 seeds was 47.3 grams.

"Burchimullo-17" variety. The shrub height was $2.2 \mathrm{~m}$, and the average yield was 4.2 $\mathrm{kg}$. Fruits were elongated with $3.0 \pm 0.04 \mathrm{~cm}$ long, and fruit weight was $3.3 \pm 0.08$ grams. The fruit flesh yield was $67.1 \%$. The fruit contained $20.7 \pm 0.40$ seeds and the weight of 1000 seeds was 41.1 grams.

"Chimgan-19" variety. The height of the bush was $2.2 \mathrm{~m}$ and the average yield was $3.5 \mathrm{~kg}$. The fruits were very large, jugular, and the average length was $3.4 \pm 0.06 \mathrm{~cm}$ and its weight was $5.6 \pm 0.14$ grams. The maximum weight of the fruit was around 7-8 g. Fruit flesh was made up $75 \%$ of the total fruit weight. The fruit contained $18.7 \pm 0.54$ seeds. The weight of 1000 seeds was 68.1 grams.

"Parkent-22" variety. The height of the bush was $2.5 \mathrm{~m}$ and the average yield was 3.1 $\mathrm{kg}$. The fruits were cup-shaped, arranged in balls on a branch, and the fruit was $3.0 \pm 0.03$ $\mathrm{cm}$ long and its weighs was $3.2 \pm 0.05$ grams. The yield of fruit flesh was $71.8 \%$. The fruit contains $22.0 \pm 0.31$ seeds. The weight of 1000 seeds was 43.2 grams.

"Parkent-25" variety. The height of the bush was $2.5 \mathrm{~m}$ and the yield was $3.0 \mathrm{~kg}$. The fruit was elongated-oblong with $2.9 \pm 0.01 \mathrm{~cm}$ long and its weighs was $3.9 \pm 0.05 \mathrm{~g}$. The 
yield of fruit flesh was $71.8 \%$. The fruit contained $21.4 \pm 0.22$ seeds. The weight of 1000 seeds was 51.0 grams.

"Hisarak-30" variety. The height of the bush was $3.0 \mathrm{~m}$ and the yield was $3.1 \mathrm{~kg}$. The fruit was large, elongated bottle-shaped, $3.1 \pm 0.04 \mathrm{~cm}$ long and weighing $3.8 \pm 0.09 \mathrm{~g}$. Fruit flesh yield was $71.0 \%$. The fruit contains $15.2 \pm 0.91$ seeds. The weight of 1000 seeds was 51.2 grams.

"Sijjak-3", "Sijjak-6", Sijjak-12" and "Chimgan-19" were selected as promising varieties, taking into account the valuable economic and biological characteristics of the fruit, such as size, productivity and fertility. "Parkent-21" and "Parkent-24", "Parkent-26" varieties were unique and promising one due to the size of fruits and amount of fruit flesh. Furthermore, "Parkent-26", "Kumushkon-29", "Parkent-23", "Chimgan-31", "Koronkul32 " were considered as promising form based on their high yield. "Silver-29" belongs to the high-vitamin "Fedchenko" variety, the surface of the fruit was hairless, and so it was a promising form for selection purposes. Fruit flesh of all selected varieties weighted more than 2.0 grams, and fruit flesh made up to $70-80 \%$ of the total fruit weight (Tables 1 and 2). 
Table 1. Morphological description of the fruits of selected rosehip varieties.

\begin{tabular}{|c|c|c|c|c|c|c|c|c|}
\hline \# & $\begin{array}{l}\text { Selected } \\
\text { varieties }\end{array}$ & $\begin{array}{l}\text { Rosehips } \\
\text { varieties }\end{array}$ & $\begin{array}{c}\text { Fruit } \\
\text { length, } \\
\mathrm{cm}\end{array}$ & $\begin{array}{c}\text { Fruit } \\
\text { diameter, } \\
\mathrm{cm}\end{array}$ & $\begin{array}{c}\text { Fruit } \\
\text { weight, } \\
\text { gr }\end{array}$ & $\begin{array}{c}\text { Fruit } \\
\text { flesh } \\
\text { weight, } \\
\text { gr }\end{array}$ & $\begin{array}{c}\text { Fruit } \\
\text { flesh, } \\
\%\end{array}$ & $\begin{array}{c}\text { Average } \\
\text { yield of } \\
\text { the } \\
\text { bush, } \\
\text { kg }\end{array}$ \\
\hline & Control & (R. ambigua) & $2.3 \pm 0.03$ & $1.4 \pm 0.01$ & $2.4 \pm 0.02$ & $1.4 \pm 0.01$ & 58.3 & 3.8 \\
\hline 1 & Korankul-1 & (R. ambigua) & $2.7 \pm 0.03$ & $1.9 \pm 0.01$ & $4.6 \pm 0.07$ & $3.4 \pm 0.05$ & 73.9 & 5 \\
\hline 2 & Sijjak -2 & (R. ambigua) & $3.0 \pm 0.03$ & $1.5 \pm 0.01$ & $3.7 \pm 0.04$ & $2.6 \pm 0.05$ & 70.2 & 4 \\
\hline 3 & Sijjak -3 & R. ambigua) & $2.9 \pm 0.02$ & $1.6 \pm 0.01$ & $4.0 \pm 0.05$ & $3.0 \pm 0.04$ & 75 & 4.5 \\
\hline 4 & Sijjak -4 & (R. ambigua) & $2.8 \pm 0.01$ & $1.7 \pm 0.01$ & $4.0 \pm 0.04$ & $3.0 \pm 0.04$ & 75 & 4.5 \\
\hline 5 & Sijjak-5 & (R. ambigua) & $2.8 \pm 0.02$ & $1.7 \pm 0.02$ & $4.3 \pm 0.08$ & $2.9 \pm 0.05$ & 67.4 & 3.5 \\
\hline 6 & Sijjak-6 & (R. ambigua) & $3.5 \pm 0.04$ & $2.1 \pm 0.02$ & $6.4 \pm 0.19$ & $5.0 \pm 0.15$ & 78.1 & 4 \\
\hline 7 & Sijjak-7 & (R. ambigua) & $2.7 \pm 0.03$ & $1.7 \pm 0.02$ & $4.1 \pm 0.06$ & $3.0 \pm 0.03$ & 73.1 & 4 \\
\hline 8 & Sijjak-8 & (R. ambigua) & $3.0 \pm 0.04$ & $1.5 \pm 0.01$ & $3.8 \pm 0.05$ & $2.7 \pm 0.04$ & 71.0 & 6 \\
\hline 9 & Sijjak-9 & (R. ambigua) & $2.9 \pm 0.03$ & $1.5 \pm 0.01$ & $3.4 \pm 0.06$ & $2.3 \pm 0.04$ & 67.1 & 4.3 \\
\hline 10 & Sijjak-10 & (R. arnoldi) & $1.9 \pm 0.03$ & $2.1 \pm 0.02$ & $4.5 \pm 0.10$ & $2.9 \pm 0.08$ & 64.4 & 3.5 \\
\hline 11 & Sijjak-11 & (R. ambigua) & $2.3 \pm 0.03$ & $1.7 \pm 0.02$ & $3.6 \pm 0.07$ & $2.6 \pm 0.05$ & 72.2 & 4.5 \\
\hline 12 & Sijjak-12 & (R. ambigua) & $2.9 \pm 0.05$ & $1.6 \pm 0.01$ & $4.1 \pm 0.10$ & $3.0 \pm 0.07$ & 73.1 & 5 \\
\hline 13 & Nanay-13 & (R. ambigua) & $2.9 \pm 0.03$ & $1.6 \pm 0.02$ & $3.3 \pm 0.08$ & $2.5 \pm 0.05$ & 75.7 & 6 \\
\hline 14 & Nanay-14 & (R. ambigua) & $2.7 \pm 0.05$ & $1.5 \pm 0.02$ & $3.2 \pm 0.06$ & $2.3 \pm 0.05$ & 71.8 & 5 \\
\hline 15 & Sijjak-15 & (R. ambigua) & $2.9 \pm 0.04$ & $1.6 \pm 0.01$ & $3.5 \pm 0.08$ & $2.8 \pm 0.04$ & 80 & 4.8 \\
\hline 16 & $\begin{array}{c}\text { Burchimullo- } \\
16 \\
\end{array}$ & (R.ambigua) & $2.8 \pm 0.03$ & $1.5 \pm 0.01$ & $3.2 \pm 0.05$ & $2.3 \pm 0.03$ & 71.8 & 3 \\
\hline 17 & $\begin{array}{c}\text { Burchimullo- } \\
17 \\
\end{array}$ & (R.ambigua) & $3.0 \pm 0.04$ & $1.5 \pm 0.01$ & $3.3 \pm 0.08$ & $2.3 \pm 0.05$ & 67.1 & 4.2 \\
\hline 18 & $\begin{array}{c}\text { Burchimullo- } \\
18 \\
\end{array}$ & (R.arnoldi) & $2.2 \pm 0.03$ & $2.0 \pm 0.03$ & $4.3 \pm 0.10$ & $3.0 \pm 0.09$ & 69.7 & 3.5 \\
\hline 19 & Chimgan-19 & (R. ambigua) & $3.4 \pm 0.06$ & $1.9 \pm 0.03$ & $5.6 \pm 0.14$ & $4.2 \pm 0.11$ & 75 & 3.5 \\
\hline 20 & Chimgan-20 & (R.Fedtschen.) & $2.6 \pm 0.02$ & $1.6 \pm 0.03$ & $2.3 \pm 0.06$ & $1.9 \pm 0.04$ & 82.6 & 2.8 \\
\hline 21 & Parkent -21 & R.canina & $2.8 \pm 0.03$ & $1.5 \pm 0.01$ & $3.6 \pm 0.06$ & $2.6 \pm 0.04$ & 72.2 & 2.8 \\
\hline 22 & Parkent -22 & R.ambigua & $3.0 \pm 0.03$ & $1.4 \pm 0.02$ & $3.2 \pm 0.05$ & $2.3 \pm 0.04$ & 71.8 & 3.1 \\
\hline 23 & Parkent -23 & R.ambigua & $3.0 \pm 0.02$ & $1.6 \pm 0.02$ & $3.8 \pm 0.07$ & $2.6 \pm 0.05$ & 68.4 & 3.5 \\
\hline 24 & Parkent -24 & R.arnoldii & $2.7 \pm 0.03$ & $2.0 \pm 0.02$ & $5.0 \pm 0.12$ & $3.9 \pm 0.06$ & 78.0 & 3.8 \\
\hline 25 & Parkent -25 & R.ambigua & $2.9 \pm 0.01$ & $1.6 \pm 0.02$ & $3.9 \pm 0.05$ & $2.8 \pm 0.04$ & 71.8 & 3.0 \\
\hline 26 & Parkent -26 & R.achburensis & $2.9 \pm 0.04$ & $1.5 \pm 0.01$ & $3.0 \pm 0.03$ & $2.4 \pm 0.06$ & 80.0 & 3.2 \\
\hline 27 & Parkent -27 & R.achburensis & $2.9 \pm 0.04$ & $1.6 \pm 0.02$ & $3.7 \pm 0.06$ & $2.6 \pm 0.02$ & 70.2 & 2.7 \\
\hline 28 & $\begin{array}{c}\text { Kumushkon } \\
-28 \\
\end{array}$ & R.Fedtschenkoana & $2.7 \pm 0.02$ & $1.7 \pm 0.03$ & $2.7 \pm 0.08$ & $2.3 \pm 0.05$ & 85.2 & 2.6 \\
\hline 29 & $\begin{array}{c}\text { Kumushkon- } \\
29 \\
\end{array}$ & R.Fedtschenkoana & $2.2 \pm 0.05$ & $2.1 \pm 0.02$ & $3.4 \pm 0.08$ & $2.7 \pm 0.04$ & 79.4 & 2.4 \\
\hline 30 & Hisarak- 30 & R.ambigua & $3.1 \pm 0.04$ & $1.6 \pm 0.02$ & $3.8 \pm 0.09$ & $2.7 \pm 0.06$ & 71.0 & 3.1 \\
\hline 31 & Chimgan- 31 & R.achburensis & $3.1 \pm 0.04$ & $1.6 \pm 0.02$ & $3.8 \pm 0.08$ & $2.9 \pm 0.06$ & 76.3 & 3.4 \\
\hline 32 & Korankul-32 & R.ambigua & $3.0 \pm 0.03$ & $1.6 \pm 0.01$ & $3.8 \pm 0.04$ & $2.8 \pm 0.02$ & 73.6 & 3.2 \\
\hline
\end{tabular}


Table 2. Seed productivity description of selected rosehip varieties.

\begin{tabular}{|c|c|c|c|c|c|c|c|c|}
\hline № & $\begin{array}{l}\text { Selected } \\
\text { varieties }\end{array}$ & Rosehip varieties & $\begin{array}{c}\text { Number } \\
\text { of seeds in } \\
\text { the fruit, } \\
\text { pcs }\end{array}$ & $\begin{array}{l}\text { Seed } \\
\text { length, } \\
\text { mm }\end{array}$ & $\begin{array}{c}\text { Seed } \\
\text { diameter, } \\
\text { mm }\end{array}$ & $\begin{array}{c}\text { Average } \\
\text { weight of } \\
\text { seed, gr }\end{array}$ & $\begin{array}{c}\text { Seed } \\
\text { yield } \\
\text { from } 1 \\
\text { kg of } \\
\text { fruit, \% } \\
\end{array}$ & $\begin{array}{c}\text { Weigh } \\
\text { t of } \\
1000 \\
\text { seeds, } \\
\text { gr } \\
\end{array}$ \\
\hline & Control & $(R$. ambigua $)$ & $27.5 \pm 0.50$ & $5.6 \pm 0.13$ & $3.7 \pm 0.07$ & 0.02 & 37.2 & 31 \\
\hline 1 & Korankul-1 & (R. ambigua) & $31.4 \pm 0.52$ & $7.1 \pm 0.13$ & $2.9 \pm 0.05$ & 0.03 & 26.1 & 37 \\
\hline 2 & Sijjak -2 & (R. ambigua $)$ & $24.3 \pm 0.99$ & $7.9 \pm 0.16$ & $3.7 \pm 0.08$ & 0.04 & 30 & 43.5 \\
\hline 3 & Sijjak-3 & (R. ambigua $)$ & $20.7 \pm 0.43$ & $5.8 \pm 0.07$ & $3.0 \pm 0.00$ & 0.04 & 25 & 44.5 \\
\hline 4 & Sijjak-4 & (R. ambigua $)$ & $26.9 \pm 0.75$ & $5.4 \pm 0.10$ & $2.9 \pm 0.05$ & 0.03 & 25 & 32 \\
\hline 5 & Sijjak-5 & (R. ambigua $)$ & $28.7 \pm 0.65$ & $5.8 \pm 0.06$ & $3.0 \pm 0.00$ & 0.04 & 33 & 48.2 \\
\hline 6 & Sijjak-6 & (R. ambigua $)$ & $29.1 \pm 0.66$ & $5.8 \pm 0.07$ & $3.0 \pm 0.00$ & 0.05 & 22 & 52.7 \\
\hline 7 & Sijjak-7 & $($ (R. ambigua $)$ & $33.9 \pm 0.93$ & $6.4 \pm 0.11$ & $3.0 \pm 0.00$ & 0.03 & 25 & 35.7 \\
\hline 8 & Sijjak-8 & (R. ambigua $)$ & $23.6 \pm 0.54$ & $7.3 \pm 0.11$ & $3.0 \pm 0.00$ & 0.04 & 29 & 43.7 \\
\hline 9 & Sijjak-9 & $($ R. ambigua $)$ & $24.9 \pm 0.83$ & $6.0 \pm 0.14$ & $3.0 \pm 0.00$ & 0.03 & 32.4 & 40.3 \\
\hline 10 & Sijjak-10 & (R. arnoldi) & $25.8 \pm 0.55$ & $5.7 \pm 0.08$ & $2.8 \pm 0.07$ & 0.04 & 35.6 & 47.8 \\
\hline 11 & Sijjak-11 & (R. ambigua $)$ & $26.3 \pm 0.87$ & $5.9 \pm 0.05$ & $3.0 \pm 0.00$ & 0.03 & 28 & 38.0 \\
\hline 12 & Sijjak-12 & $($ R. ambigua $)$ & $20.0 \pm 0.62$ & $6.5 \pm 0.10$ & $3.0 \pm 0.00$ & 0.04 & 25 & 46.9 \\
\hline 13 & Nanay-13 & $($ R. ambigua $)$ & $16.5 \pm 0.46$ & $6.5 \pm 0.09$ & $3.0 \pm 0.00$ & 0.04 & 25.3 & 47.3 \\
\hline 14 & Nanay-14 & (R. ambigua $)$ & $20.5 \pm 0.50$ & $5.6 \pm 0.08$ & $3.0 \pm 0.00$ & 0.03 & 28.2 & 33.1 \\
\hline 15 & Sijjak-15 & (R. ambigua $)$ & $28.7 \pm 0.66$ & $6.6 \pm 0.08$ & $2.9 \pm 0.06$ & 0.04 & 20 & 41.2 \\
\hline 16 & $\begin{array}{c}\text { Burchimull } \\
\text { o-16 }\end{array}$ & (R.ambigua) & $21.5 \pm 0.40$ & $6.3 \pm 0.08$ & $3.0 \pm 0.00$ & 0.04 & 28.2 & 48.3 \\
\hline 17 & $\begin{array}{c}\text { Burchimull } \\
0-17\end{array}$ & (R.ambigua) & $20.7 \pm 0.40$ & $6.4 \pm 0.08$ & $2.8 \pm 0.07$ & 0.04 & 30.4 & 41.1 \\
\hline 18 & $\begin{array}{c}\text { Burchimull } \\
\text { o-18 }\end{array}$ & (R.arnoldi) & $29.3 \pm 0.64$ & $5.6 \pm 0.08$ & $2.9 \pm 0.05$ & 0.04 & 30.3 & 48.6 \\
\hline 19 & Chimgan-19 & (R. ambigua $)$ & $18.7 \pm 0.54$ & $6.4 \pm 0.08$ & $3.8 \pm 0.07$ & 0.06 & 25 & 68.1 \\
\hline 20 & Chimgan-20 & (R.Fedtschen) & $11.3 \pm 0.67$ & $6.3 \pm 0.08$ & $2.9 \pm 0.06$ & 0.043 & 17.4 & 46.5 \\
\hline 21 & $\begin{array}{c}\text { Parkent - } \\
21 \\
\end{array}$ & R.canina & $19.9 \pm 0.67$ & $5.9 \pm 0.05$ & $3.6 \pm 0.09$ & 0.04 & 27.4 & 47.1 \\
\hline 22 & $\begin{array}{c}\text { Parkent - } \\
22\end{array}$ & R.ambigua & $22.0 \pm 0.31$ & $5.5 \pm 0.08$ & $3.6 \pm 0.09$ & 0.03 & 27.7 & 43.2 \\
\hline 23 & $\begin{array}{c}\text { Parkent - } \\
23 \\
\end{array}$ & R.ambigua & $36.3 \pm 0.03$ & $6.4 \pm 0.08$ & $3.1 \pm 0.04$ & 0.04 & 30.4 & 43.0 \\
\hline 24 & $\begin{array}{c}\text { Parkent - } \\
24\end{array}$ & R.arnoldii & $34.2 \pm 0.44$ & $4.5 \pm 0.08$ & $3.4 \pm 0.08$ & 0.03 & 21.7 & 44.2 \\
\hline 25 & $\begin{array}{c}\text { Parkent - } \\
25 \\
\end{array}$ & R.ambigua & $21.4 \pm 0.22$ & $6.5 \pm 0.09$ & $3.0 \pm 0.01$ & 0.05 & 28.0 & 51.0 \\
\hline 26 & $\begin{array}{c}\text { Parkent - } \\
26 \\
\end{array}$ & R.achburensis & $19.1 \pm 0.61$ & $4.5 \pm 0.09$ & $3.0 \pm 0.01$ & 0.04 & 19.2 & 40.8 \\
\hline 27 & $\begin{array}{c}\text { Parkent - } \\
27\end{array}$ & R.achburensis & $24.5 \pm 0.68$ & $5.4 \pm 0.09$ & $3.0 \pm 0.01$ & 0.04 & 28.4 & 38.02 \\
\hline 28 & $\begin{array}{c}\text { Kumushkon } \\
-28 \\
\end{array}$ & R.Fedtschenkoana & $8.8 \pm 0.66$ & $6.2 \pm 0.07$ & $3.2 \pm 0.07$ & 0.04 & 14.3 & 46.02 \\
\hline 29 & $\begin{array}{c}\text { Kumushkon } \\
-29\end{array}$ & R.Fedtschenkoana & $24.0 \pm 0.74$ & $5.5 \pm 0.09$ & $3.4 \pm 0.09$ & 0.03 & 19.4 & 48.02 \\
\hline 30 & Hisarak 30 & R.ambigua & $15.2 \pm 0.91$ & $6.2 \pm 0.14$ & $3.2 \pm 0.07$ & 0.06 & 27.8 & 51.2 \\
\hline 31 & Chimgan 31 & R.achburensis & $22.2 \pm 0.61$ & $4.9 \pm 0.06$ & $3.0 \pm 0.01$ & 0.04 & 23.4 & 49.0 \\
\hline 32 & Korankul 32 & R.ambigua & $22.9 \pm 0.16$ & $5.6 \pm 0.09$ & $3.4 \pm 0.08$ & 0.04 & 25.6 & 48.2 \\
\hline
\end{tabular}

\section{Conclusions}

The fertility of the rosehips fruit was considered a valuable selection trait, and it was taken into account in distinguishing promising varieties. Rosehips seeds contain "rosehips oil", which contains $10 \mathrm{mg} \%$ carotene, $200 \mathrm{mg} \%$ vitamin E, linoleic (56.71\%) and oleic $(29.32 \%)$ acids. This oil is similar to retail oil in terms of pharmacological activity [3]. Due to the lack of thorns in the generative branches, the Sijjak-6 form was an interesting object for selection purposes. It was noted that the main part of the selected rosehips varieties in the mountain villages of Bostanlik district belong to the species of doubtful rosehips (Rosa ambigua N. Russanov) 
"Sijjak-3", "Sijjak-6", Sijjak-12" and "Chimgan-19" were selected as promising varieties, taking into account the valuable economic and biological characteristics of the fruit, such as size, productivity and fertility. "Parkent-21" and "Parkent-24", "Parkent-26" varieties were unique and promising one due to the size of fruits and amount of fruit flesh. Furthermore, "Parkent-26", "Kumushkon-29", "Parkent-23", "Chimgan-31", "Koronkul32 " were considered as promising form based on their high yield.

\section{References}

1. I. Pećinar, D. Krstić, G. Caruso, J. Popović-Djordjević, Royal Society Open Science, 8, 3 (2021)

2. E. Berdiev, Bulletin of Agrarian Science, 1, 51 (2013)

3. Y. Peng, F. Li, N. Xu, R. Kulmatov, K. Gao, G. Wang, Y. Zhang, Y. Qiao, Y. Li, H. Yang, S. Hao, Q. Li, S. Khasanov, Chinese Journal of Eco-Agriculture, 29(2), 312-324 (2021)

4. H. Ilyasoğlu, International Journal of Food Properties, 17, 7 (2014)

5. I. Aslanov, S. Khasanov, Y. Khudaybergenov, M. Groll, Ch. Opp, F. Li, E. Ramirez Del-Valle, In E3S Web of Conferences, 227, 02005 (2021)

6. S. Isaev, S. Khasanov, Y. Ashirov, T. Karabaeva, A. Gofirov, In E3S Web of Conferences, 244, 02012 (2021)

7. C. Fan, C. Pacier, D. Martirosyan, Functional Foods in Health and Disease, 4, 12 (2014)

8. M. Günes, African Journal of Biotechnology, 9, 38 (2010)

9. G. Angelov, S. Boyadzhieva, S. Georgieva, Central European journal of chemistry. 12, 4 (2014)

10. M. Michalak, A. Kieltyka-Dadasiewicz, Herba Polonica, 64, 4 (2018)

11. S. Milić, M. Kostić, P. Milić, V. Vučić, A. Arsić, V. Veljković, O. Stamenković, Chemical Engineering \& Technology, 43, 12 (2020)

12. Z. Ryabinina, O. Lyavdanskaya, G. Bastaeva, S. Lebedev, R. Kalyakina, M. Ryabuhina, Earth and Environmental Science, 624, 1 (2021)

13. S. Tolekova, T. Sharmanov, Y. Sinyavskiy, R. Berzhanova, R. Mammadov, Ö. Aksoy R. Yusifli, International Journal of Secondary Metabolite, 7, 3 (2020)

14. S. Isaev, S. Khasanov, Y. Ashirov, A. Gofirov, T. Karabaeva, In E3S Web of Conferences, 244, 02047 (2021) 